\title{
Analisis Interaksi Simbolik pada Konten Ofensif Iklan Grab \#pilihaman
}

\author{
Sri Seti Indriani ${ }^{1}$, Lilis Puspitasari ${ }^{2}$, dan Evi Rosfiantika ${ }^{3}$ \\ 1,2,3Program Studi Televisi dan Film, Fakultas Ilmu Komunikasi, \\ Universitas Padjadjaran, Bandung
}

\begin{abstract}
ABSTRAK
Iklan memiliki sifat yang menyerap dan terkadang berlebihan. Iklan dapat ditemukan di setiap platform area lingkungan kita, baik secara cetak maupun online, sehingga menyerap perhatian kita. Pertumbuhan belanja iklan sepanjang Januari-September 2018 menunjukkan tren positif di angka 5 persen, dengan total belanja iklan baik di media televisi dan cetak mencapai Rp 114,4 Triliun. Pordusen iklan berlomba-lomba bersaing merebut perhatian publik agar supaya iklan produk mereka terjual dan terbeli. Banyak cara yang dilakukan pengiklan agar menarik perhatian publik. Perhatian tersebut bisa bersifat positif maupun negatif dan bahkan tidak etis untuk ditayangkan. Salah satu iklan yang ditarik kembali oleh produsennya adalah iklan video kampanye Grab \#PilihAman karena menuai berbagai reaksi dari masyarakat. Iklan tersebut diunduh oleh Grab di YouTube pada tahun 2016. Penelitian ini berupaya untuk menjelaskan bagaimana iklan tersebut menggunakan taktik pujian dalam menekankan sebuah kebenaran dan bagaimana penonton melihat iklan video kampanye Grab\#PilihAman tersebut. Metode penelitian yang digunakan adalah metode penelitian deskriptif-kualitatif. Teknik pengambilan data menggunakan wawancara, studi dokumentasi dan observasi. Beberapa informan yang merupakan pemerhati iklan ditarik sebagai subjek penelitian. Hasil penelitian mengungkap bahwa adanya empat cara iklan tersebut menarik perhatian publik: (1) Pseudo_claims, (2) Comparison with an unidentified other, (3) Irrelevant Comparisons dan (4) juxtaposition. Penonton melihat iklan konten Grab tersebut sebagai hal yang: (1) ofensif (penyerang), (2) berlebihan (overclaim), (3) ektsrim dan (4) tidak etis.
\end{abstract}

Kata-kata Kunci: Konten; iklan; persepsi; Grab online; produk

\section{Symbolic Interaction Analysis of The Advertisement Official Grab Content \#pilihaman}

\begin{abstract}
Advertising is pervasive and excessive. Advertisements can be found on every platform of our environment, both printedand online, so that it absorbs our attention. The growth of advertising spending throughout January-September 2018 shows a positive trend at 5 percent, with total advertising spending in both television and print media reaching $R p 114.4$ trillion. Advertisement manufacturers compete to win public attention so that their product advertisements are sold and bought. Many ways that advertisers do to attract public attention. Such attention can be both positive and negative and even unethical to air. One of the advertisements that was recalled by the producers was the Grab campaign \#PilihAman video advertisement because of reaping various reactions from the public. This video campaign advertisement was uploaded in YouTube in the year 2016 This study aims to explain how this advertisement use puffery to supress the truth and how the audience see the Grab video campaign Advertisement \#PilihAman fenomena. The research method used is a descriptive-qualitative research. Data collection techniques used were interviews, study documentation and observation. The results of the study revealed that the advertisement used: (1) Pseudo claims, (2) Comparison with an unidentified other, (3) Irrelevant Comparisons and (4) juxtaposition. Audiences saw this advertisement as: (1) offensive, (2) overclaiming, (3) extreme and (4) unethical.
\end{abstract}

Keywords: Content; advertising; perception; grab online; produc

Korespondensi: Sri Seti Indriani. Universitas Padjadjaran, J1. Raya Bandung-Sumedang Km 21, Jatinangor 45363.Email:seti@unpad.ac.id 


\section{PENDAHULUAN}

Iklan ada pada tahap kejenuhan karena manusia sepertinya dikelilingi oleh iklan. Iklan yang bersifat "pervasive" atau dengan kata lain menyerap perhatian kita semua karena berada di hampir setiap tempat manusia berada (Potter, 2014). Menurut Nielson, sebuah perusahaan global yang menyediakan pemahaman komprehensif pada apa yang konsumen tonton (Watch) dan beli (Buy), pertumbuhan belanja iklan menunjukkan trend yang positif dari tahun ke tahun. Di Indonesia, total belanja iklan tahun 2017 meningkat 8\% dari tahun sebelumnya dengan nilai yang mencapai Rp 145.Triliun. Media TV mendominasi iklan sebesar 80\% dari total belanja iklan yang tumbuh $12 \%$ dibandingkan tahun sebelumnya (Lubis, 2018) dibandingkan media massa lainnya.

Lembaga riset Nielsen juga melaporkan, bahwa pertumbuhan belanja iklan sepanjang Januari-September 2018 menunjukkan tren positif di angka 5 persen, dengan total belanja iklan baik di media televisi dan cetak mencapai Rp 114,4 Triliun. Kategori Layanan Online berada di urutan kedua dan tumbuh 45 persen dengan total belanja iklan mencapai $\mathrm{Rp} 2,4$ Triliun (Harry, 2018). Asian Games pada tahun 2018 juga turut andil dalam tren peningkatan iklan, Grab yang merupakan aplikasi online yang menawarkan jasa angkut menjadi merek dengan belanja iklan tertinggi lainnya sebesar Rp 28,7 miliar (Baskoro, 2018).

Persaingan produsen untuk menjadi pilihan para konsumen semakin hari semakin meninggi, produsen berlomba-lomba mengemas iklan produk mereka sedemikian rupa untuk terus menarik perhatian publik. Iklan memiliki beban dan strategi yang sama seperti sebuah film. Strategipromosifilm harus terencana sedemikian rupa sehingga mendapatkan target pasar yang baik juga. Namun, mempromosikan sebuah film memang tidak mudah; tim produksi film harus kreatif dan aktif dalam mempromosikan film tersebut (Permana, Puspitasari, \& Indriani, 2018). Hal ini sama juga yang harus dilakukan oleh pengiklan. Pengiklan dituntut kreatifitasnya agar menarik bagi penonton.Berbagai macam iklan pun kian hari kian menarik publik dengan caranya masing-masing.Iklan-iklan tersebut terus memberikan persepsi dan pengaruh pada publik. Persepsi publik terhadap sebuah iklan dapat mempengaruhi bagaimana masyarakat memilih produk-produk tersebut.Iklan efektif dalam mempengaruhi persepsi orang-orang tentang sebuah produk, iklan juga merupakan salah satu bentuk komunikasi pemasaran yang mempunyai porsi paling besar dalam membentuk positioning produk (Winarni, 2010).

Persepsimasyarakat padasebuahiklandapat bersifat positif maupun negatif. Iklan dengan 
persepsi positif menimbulkan pembelian yang disebabkan oleh informasi produk yang jelas dan rinci (Hakim \& Susilowati, 2013). Maka persepsi negatif diasumsikan kebalikannya. "consumers believe advertising often violates broad ethical norms. In addition, the degree to which consumers judge advertising as ethical or unethical varies as a function of their relativism and idealism" (Triesie, Weigold, Conna, \& Garrison, 1994). Pernyataan tersebut menekankan bagaimana konsumen merasa bahwa sering kali iklan bersifat tidak etis, hal ini mengasumsikan bagaimana sebuah persepsi negatif publik terhadap sebuah iklan timbul dikarenakan publik merasa iklan tersebut telah melanggar beberapa nilai-nilai etika.

Tidak jarang iklan-iklan yang kontraversial karena bersifat tidak etis di berbagai media massa memaksa pihak pengiklan untuk menarik iklan dari peredaran atau mengganti materi iklan. Salah satu iklan yang ditarik oleh Komisi Penyiaran Indonesia (KPI) adalah iklan Mie Sedap versi Papa Hidup Lagi yang disiarkan pada tahun 2010. Iklan tersebut dianggap telah melanggarPasal 49 ayat (1) Standar Program Siaran (SPS) KPI yang menyatakan soal kewajiban berpedoman pada Etika Pariwara Indonesia (EPI). Dalam EPI Bab III, A. 3.1.2 menyebutkan bahwa "iklan tidak boleh memperlihatkan anak-anak dalam adegan-adegan yang menyesatkan atau tidak pantas dilakukan oleh mereka". Iklan tersebut dianggap mengajarkan anak untuk berbohong untuk menutupi kemalasan Ayah-nya (DH, 2016).

Iklan-iklan kontraversial lainnya seperti iklan sandal New Era, dan iklan cat kayu dan besi Avian juga mendapatkan teguran dari KPI Pusat yang melayangkan surat teguran kepada lima stasiun antara lain TV One, Global TV, SCTV, Trans 7 dan PT Cipta TPI karena telah dinilai melanggar aturan P3 dan SPS KPI tahun 2012 (Utami, 2018). Iklan-iklan tersebut dianggap kurang etis karena melanggar etika kesopanan.

Penelitian ini berupaya untuk melihat salah satu iklan Grab versi 'Dinda anak saya'dengan hashtag \#PilihAmanyang oleh pihak Grab-nya sendiri akhirnya memutuskan untuk mengganti video tersebut karena adanya berbagai reaksi dari masyarakat. Penelitian ini bertujuan untuk menjelaskan bagaimana audiens melihat iklan Grab ini dan bagaimana iklan tersebut menjual produk mereka melalui analisis interaksi simbolik. Meskipun Iklan ini sudah tidak tayang di platform nasional, namun iklan ini masih bisa diakses melalui Youtube. Iklan ini tidak memengaruhi bisnis Grabnya sendiri, karena Grab memiliki iklan-iklan lainnya yang menarik bagi penonton.

Manfaat dari penelitian ini secara teoretis diharapkan dapat memperkaya penelitian- 
penelitian yang berkaitan dengan periklanan. Hasil penelitian ini juga dapat dijadikan refrensi bagi mahasiswa jurusan televisi dan film.Sedangkan secara praktis, penelitian ini diharapan menjadi masukan dan pertimbanganpertimbangan bagi pengiklan maupun tim produksi media massa baik secara online maupun tidak dalam pembuatan sebuah konten iklan agar sebuah iklan tidak disalahartikan oleh penonton.

\section{TINJAUAN PUSTAKA}

Iklan merupakan salah satu bentuk khusus komunikasi yang biasanya digunakan pengusaha untuk mengarahkan komunikasi persuasi pada pembeli sasaran dan masyarakat. Periklanan merupakan suatu alat untuk membuka komunikasi dua arah antara penjual dengan pembeli, sehingga keinginan mereka dapat terpenuhi dengan cara yang efisien dan efektif. Iklan merupakan salah satu bentuk pesan yang disampaikan melalui media massa. Iklan bersifat mempersuasi khalayak, dengan harapan bahwa khalayak akan terpengaruh dengan isi iklan tersebut (Dapu, Kawengian, \& Waleleng, 2015).

Fungsi iklan yang membujuk atau memengaruhi masyarakat berarti bahwaiklan tidak hanya bersifat memberi informasi, lebih dari itu iklan memiliki kemampuan yang potensial dalam menyatakan bahwa produknya lebih unggul dari produk lainnya.Walaupun pada umumnya orang tidak ingin dibujuk atau didorong untuk membeli produk yang sudah jelas dapat memuaskan kebutuhan dan keinginan mereka. Orang sering mengatakan iklan adalah media mempromosikan suatu produk (Fauziah \& Puspita, 2018).

Iklan juga berfungsi untuk menciptakan kesan. Dengan sebuah iklan orang akanmempunyai kesan tertentu tentang apa yang diiklankan. Dalam hal ini pemasang iklan selalu berusaha untuk menciptakan iklan sebaik dan skreatif mungkin agar menarik perhatian masyarakat. Lalu fungsi terakhir yaitu bahwa iklan digunakan untuk memuaskan keinginan masyarakat. Sebelum memilih dan membeli produk, terkadang orang lain diberitahu terlebih dahulu. Iklan merupakan suatu alat yang dapat dipakai untuk mencapai tujuan itu sendiri berupa pertukaran yang saling memuaskan dan juga merupakan salah satu alat komunikasi yang sangat efisien bagi para penjual.

Tujuan periklanan merupakan tugas komunikasi khusus serta tingkat pencapaian yang dicapai dengan jumlah pemirsa tertentu dan dalam jangka waktu tertentu yang kemudian dapat diklasifikasikan sebagai berikut: (a) Iklan informatif bertujuan menciptakan kesadaran merk dan pengetahuan tentang produk atau fitur baru produk yang ada; (b) Iklan persuasif 
bertujuan menciptakan kesukaan, preferensi, keyakinan, dan pembelian

produk atau jasa. Beberapa iklan persuasif menggunakan iklan komparatif, yang membuat perbandingan eksplisit tentang atribut dua merek atau lebih; (c) Iklan pengingat bertujuan menstimulasikan pembelian berulang produk atau jasa; (d) Iklan penguat bertujuan meyakinkan pembeli saat ini bahwa mereka melakukan pilihan tepat (Kotler \& Keller, 2009).

Kritik terhadap iklan menyebutkan bahwa iklan bersifat menipu 'advertising is deceptive', namun sebenarnya iklan tidak menipu karena iklan sebenarnya menghindari klaim-klaim yang bersifat eksplisit yang dapat dinilai kejujurannya. Maka sebaliknya iklan menggunakan puffery (pujian yang berlebihan) dalam menekankan kebenaran. Jamieson dan Campbell (1988) menyebutkan enam cara iklan menekankan kebenaran yaitu (1) pseudo-claims, (2) comparison with an unidentified other, (3) comparisons of the product to its earlier form, (4) irrelevant comparisons, (5) pseudo-survey dan (6) juxtaposition (Potter, 2014).

Pseudo-claims, merupakan klaim yang diciptakan oleh pengiklan namun tidak diinformasikan bagaimana klaim tersebut dilakukan. Comparison with an unidentified other, dilakukan ketika pengiklan melakukan perbandingan dengan pihak lain yang tidak diidentifikasikan. Comparisons of the product to its earlier form, ini merupakan salah satu cara pengiklan menekankan peningkatan pada produknya ketika dibandingkan dengan produk lamanya. Irrelevant comparisons, merupakan perbandingan yang dilakukan oleh pengiklan yang kurang relevan.

Pseudo-survei adalah ketika pengiklan menyatakan bahwa produk yang diiklankan telah melewati beberapa survei. Namun tidak diinformasikan survei seperti apa. Cara yang terakhir adalah juxtaposition. Juxtaposition adalah ketika pengiklan menampilkan seorang yang menggunakan produk mereka dan terlihat bahwa orang tersebut tersenyum, sehingga mengasumsikan bahwa orang tersebut bahagia dan puas memilih dan menggunakan produk tersebut.

Iklan juga bisa dikatakan tidak etis atau tidak pantas untuk ditayangkan. Seperti contoh-contoh sebelumnya adanya beberapa iklan yang ditarik peredarannya adalah karena alasan nahwa iklan tersebut tidak etis. Adapun beberapa hal yang harus diperhatikan ketika sebuah iklan dikatakan tidak etis sebagai berikut (Gehi, 2013): (1) Ketika sebuah iklan sudah menjatuhkan pesaingnya, atau produk saingnya; (2) Ketika sebuah iklan memberikan informasi palsu yang dapat memberikan kesalahpahaman kepada publik mengenai sebuah produk; (3) Ketia iklan tersebut memberikan informasi 
yang bermanfaat mengenai produknya dan efek sampingnya; dan (4) Ketika iklan tersebut tidak bermoral.

Grab didirikan oleh Anthony Tan dan Hooi Ling Tan yang merupakan warga negara Malaysia, mereka melihat adanya dampak negatif dari tidak efisiennya sistem transportasi yang ada pada saat itu. Layanan Grab ditujukan untuk memberikan alternatif berkendara bagi para pengemudi dan penumpang yang menekankan pada kecepatan, keselamatan, dan kepastian. Grab sendiri telah hadir di Indonesia pada bulan Juni 2012 sebagai aplikasi pemesanan taksi dan sejak itu telah memberikan beragam pilihan transportasi seperti mobil dan ojek.

Iklan Grab \#PilihAman merupakan video yang memiliki tujuan untuk mengkampanyekan keselatan dan keamanan seseorang dalam berkendaraan. Kampanye tersebut bertujuan agar publik memilih jasa transportasi yang aman dalam berpergian. Jikan dalam memilih jasa transportasi yang aman, makan kejadian buruk seperti kecelakaan dalam lalu lintas dapat dihindari. Video kampanye seperti ini dapat lebih efektif karena menyampaikan pesan dalam bentuk verbal dan nonverbal lewat YouTube. YouTube menyediakan fasilitas bagi penggunanya untuk saling berinteraksi seperti subscribe, like/dislike, views dan comment, yang mana fasilitas interaksi tersebut dapat memengaruhi eksistensi dari video yang ada di YouTube tersebut (Azzahrani, 2018).

Video advertising pada YouTube dan TV advertising bersifat audio visual sehingga memiliki banyak persamaan seperti komponen video yaitu setting, talent, pencahayaan, grafis, warna, simbol dan komponen audio yaitu voice over, musik atau jingle, sound effects (Nurfebiaraning, 2016). Dalam periklanan, media online dijadikan sebagai salah pilihan untuk beriklan dengan cepat dan murah. Hanya dengan mengakses internet sebuah perusahaan dapat mengiklankan produk yang mereka akan rilis dan jual di dalam pasar (Ammarie \& Nurfebiaraning, 2018).

Iklan video kampanye Grab ini dilengkapi dengan Hastag atau simbol \#. Hashtag itu sendiri merupakan sebuah mediasi untuk menciptakan sebuah komunitas virtual. Komunitas virtual tersebut merupakan orang-orang yang memiliki ketertarikan yang sama dan berbagi informasi. "Computer Mediated Communication or CMC is able to present a virtual community, where the people inside have the same interest to share information related to events, activities, competitions, entertainment, history, event and others in Semarang City for publication" (Mulyadi \& Fitriana, 2018).

Simbol Hashtag \#PilihAman menyatakn bahwa Grab merupakan salah satu anggota yang menyosong pilihan-pilihan aman. 
Mereka mendukung dan menekankan pilihan yang sifatnya aman. Hashtag ini dipilih karena adanya data dari WHO (World Health Organization) yang menyatakan adanya laporan status global tahun 2015 mengenai keamanan berkendaraan. Laporan tersebut menyebutkan lebih dari sepertiga (34 persen) kematian akibat kecelakaan lalu lintas di Asia Tenggara dialami oleh pengguna kendaraan roda dua atau roda tiga. Sementara itu, angka kecelakaan motor yang berakibat kematian di Indonesia lebih tinggi dari rata-rata yaitu sebesar 36 persen, di mana lebih dari 80 persen dari kendaraan yang terdaftar merupakan motor atau kendaraan bermotor roda dua atau roda tiga (Grab.com, 2016). Ini menjadi alasan Grab agar kesadaran berkendara secara aman harus menjadi prioritas masyarakat luas.

George Herbert Mead mengatakan bahwa manusia menciptakan simbol-simbol yang bermakna dan signifikan. Simbol tersebut merupakan hasil dari interaksi sosial yang berupa tindakan-tindakan sosial. Berbeda dengan kaum behavioralisme, Mead menyatakan bahwa manusia melakukan tindakan tidak hanya karena adanya stimulu dari faktor-faktor luar, namun manusia sendiri memiliki kekuatan untuk memutuskan sesuatu. Tindakan itu sendiri terbagi ke dalam empat tahapan yaitu: (1) impuls, (2) persepsi, (3) manipulasi dan (4) konsumasi (Ritzer, 2014).
Impuls merupakan dorongan hati yang meliputi rangsangan spontan yang berhubungan dengan alat indra namun memikirkan reaksi yang tepat. Reaksi tersebut berdasarkan pengalaman dan mengantisipasi. Persepsi menyelidiki dan bereaksi terhadap rangsangan yang berhubungan dengan impuls dan memilahmana yang perlu diperhatikan dan mana yang perlu diabaikan. Manipulasi merupakan tahap jeda yang penting dalam proses tindakan agar tanggapan tidak diwujudkan secara spontan. Ini adalah saat seseorang melakukan pertimbangan apakah melakukan atau tidak melakukan tindakan tersebut. Tahap konsumasi merupakan tahap pelaksanaan untuk memuaskan dorongan hati.

Seperti yang telah diungkapkan di atas bahwa persepsi seseorang terhadap sebuah iklan dapat memberikan pengaruh agar iklan tersebut efektif dan mendorong orang tersebut untuk kemudian membeli atau menggunakan jasa yang ditawarkan oleh iklan tersebut. Mead mengatakan bahwa persepsi merupakan salah satu tahapan dalam tindakan manusia. Tindakan seseorang tidak hanya berasal dari faktor-faktor eksternal, namun juga internal yang terdiri dari empat tahapan, yaitu: impuls, persepsi, manipulasi dan kemudian konsumsi. Persepsi yang merupakan tahapan kedua adalah ketika seseorang mnyelidiki dan bereaksi terhadap rangsangan yang berhubungan dengan impuls. Persepsi melibatkan rangsangan yang baru 
masuk maupun citra mental yang ditimbukannya (Ritzer, 2014).

Persepsi adalah pengalaman tentang objek, peristiwa, atau hubungan-hubungan yang diperoleh dengan menyimpulkan informasi dan menafsirkan pesan, yang kemudian memberikan makna pada stimulus inderawi (Rakhmat, 2013). Proses terjadinya persepsi yaitu apabila objek menimbulkan stimulus dan stimulus mengenai alat indera atau reseptor (Walgito, 2004). Seseorang secara aktif akan mempresepsikan sesuatu sesuai dengan pengalamannya tentang objek tersebut. Seperti pada iklan Grab versi 'Dinda anak saya', masyarakat yang melihat iklan tersebut akan dengan sendirinya memaknai simbol-imbol verbal maupun nonverbal yang terdapat dalam iklan tersebut sesuai dengan pengalamannya. Hal ini berkaitan dengan teori interaksi simbolik, dimana manusia memiliki kekuatan untuk melakukan sesuatu dan menginterpretasikan sesuatu secara aktif dan kreatif. Interaksi simbolik memiliki beberapa pemahaman yaitu: (1) "People interact with people through symbols that have meanings attached which are internalized through the culture/habits", manusia berinteraksi menggunakan simbol-simbol yang memiliki makna dan terinternalisasi melalui budaya dan kebiasaan; (2) "shared subjective agreement", adanya persetujuan subjektif bersama; dan (3) "shared symbols", adanya simbol-simbol yang dimaknai secara bersama.

Penelitian ini menggunakan analisis interaksi simbolik, informan-informan yang menjadi subjek penelitian yang telah melihat iklan video kampanye Grab \#PilihAman memaknai iklan tersebut melalui simbol-simbol visualisasi baik verbal maupun nonverbal. Simbol-simbol tersebut memiliki makna bersama karena terinternalisasi melalui budaya dan kebiayaan dalam lingkungan mereka.

\section{METODE PENELITIAN}

Metode penelitian ini bersifat deskriptifkualitatif. Penelitian kualitatif mencoba mempertahankan bentuk dan isi perilaku manusia dan menganalisis kualitas-kualitasnya (Mulyana, 2001). Metode deskriptif merupakan penelitian yang tidak menggunakan hipotesis dan variabel melainkan hanya menggambarkan dan menganalisis kejadian atau sebuah fenome yang tidak diberlakukan perlakuan khusus sebelumnya.

Teknik pengumpulan data yangdigunakan dalam penelitian ini adalah dengan cara wawancara dan studi dokumentasi. Tujuh informan yang menjadi subjek penelitian melalui purposive sampling telah diwawancara. Informan adalah mereka yang pernah melihat iklan video kampanye Grab \#PilihAman. Ketujuh informan juga adalah mereka yang terbiasa mengunakan baik aplikasi Grab 
maupun pengguna jasa ojek pangkalan.

\section{HASIL DAN PEMBAHASAN}

Penelitian ini berupaya untuk menjelaskan bagaimana publik melihat iklan video kampanye Grab \#PilihAman, dan bagaimana iklan tersebut mencoba menarik perhatian publik. Iklan ini berupa video kampanye yang berdurasi 45 detik yang diunggah Grab lewat channel YouTubenya pada hari Minggu 18 September 2016.. Sebuah iklan yang efektif tentu harus menarik perhatian publik, seperti yang dikemukakan oleh Moriarty et.al:

"An effective ad is relevant, and original and has impact - which is referred to as ROI of creativity. Ideas have to be relevant and mean something to the target audience. Original means one of a kind-an advertising idea is creative when it is novel, fresh, unexpected, and unusual. Because it is novel, it is surprising and get your attention. To be effective, the idea also must have impact, which means it makes an impression on the audience," (Nurfebiaraning, 2016).

Efektivitas sebuah iklan bersifat relatif. Iklan harus memiliki orisinil dan memiliki dampak. Iklan yang kreatif, tidak diharapkan dan berbeda dengan hal yang lain bisa membuat sebuah kesan tersendiri bagi penonton (Nurfebiaraning, 2016). Hal ini berlaku pada iklan video kampanye Grab \#PilihAmankarena hingga penelitian ini dilakukan, iklan video kampanye yang diunggah lewat YouTube ini telah dilihat sebanyak 27148 kali. Meskipun menuai berbagai reaksi, namun iklan ini tidak mempengaruhi penurunan penggunaan jasa transportasi GrabBike. Berbagai reaksi terlihat pada kotak komentar Youtube. Ini memperlihatkan beberapa tanggapan dan reaksi terhadap iklan tersebut. Gambar 1 memperlihatkan beberapa komentar yang termuat di bawah video iklan kampanye "Dinda Anak saya" hashtag \#Pilihaman.

Komentar-komentar yang terlihat ada yang bersifat positif namun ada pula yang bersifat negatif. Dua dari empat komentator mempresepsikan bahwa iklan tersebut seperti menjatohkan ojek pangkalan, dan dua lainnya lebih melihat sisi positifnya. Komentator yang bernama Fransisca sepertinya memahami

(6)

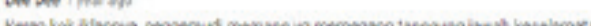

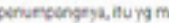

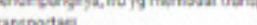
$16+\%$ mant

$\mathbf{0}$

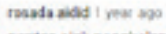

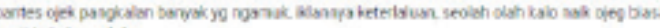
pess bavidioncelahe 1. ? + nero

(2)

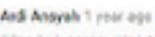

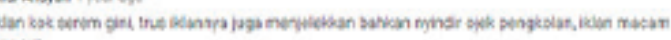
spa in 11 of $\mathrm{prry}$ viex reply -

(9) Rruises Meis 1 yar 490

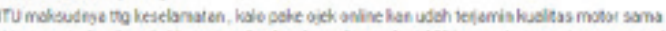

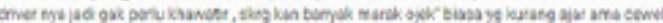

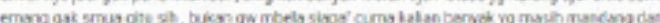

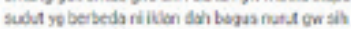

it 2 - nero

sumber:https://www.youtube.com/ watch?v=IIV8Rosy5aw, 2018

Gambar 1 Komentar nietzen mengenai video kampanye video iklan Grab versi "Dinda Anak saya" \#PilihAman 
maksud langsung dari iklan Grab \#Pilih aman dan percaya bahwa ojek-ojek online terjamin kualitas motornya. Ia menegaskan bahwa iklan Grab tersebut bagus. Sebaliknya, komentator bernama Rosada dan Ardi merasa iklan tersebut keterlaluan karena secara langsung menyindir para ojek pangkalan. Iklan tersebut juga dikatakan serem, mungkin karena adanya visualisasi darah dan luka yang cukup banyak. Selain itu, ada 159 jempol yang mengarah ke atas yang berarti, publik suka dengan iklan video kampanye ini sedangkan ada juga 58 lainnya yang memilih jempol yang mengarah ke bawah. Untuk menjelaskan konteksnya, ada voice-over lelaki yang menjadi ayah Dinda. Voice-over itu mengindikasikan Dinda berisiko mengalami kecelakaan jika memilih transportasi yang tak aman (Bohang, 2016). Berikut adalah voiceover yang terdapat dalam iklan video kampanye tersebut:

"ini Dinda anak saya, umurnya 20 tahun dan dia pengen menjadi penyanyi, sebentar lagi dia harus mengambil keputusan besar, kalo salah pilih Dinda nggak bakal menjadi penyanyi.. Dinda nggak bakal ketemu teman-temannya lagi..ibunya atau saya lagi.Tapi Dinda memilih yang benar."

Voice-Over pertama yang disinyalir sebagai bapaknya Dinda mengindikasikan bahwa Dinda memiliki mimpi untuk menjadi seorang penyanyi, namun apabila Dinda tidak memilih sebuah keputusan yang benar, Dinda tidak akan bertemu dengan teman-temannya, ibunya bahkan bapaknya lagi. Hal ini mengasumsikan bahwa Dinda akan meninggal apabila memilih yang salah. Kemudian adanya pergantian suara yang mewakilkan dari pihak Grab:

“..apakah biker lulus pelatihan? Apakah dokumennya lengkap? Apakah motornya dirawat secara rutin?. Dengan Grab jawabnya selalu Iya. Karena anda tak tergantikan"

Voice-over kedua yang mewakilkan pihak Grab menekankan bahwa Grab merupakan pilihan yang benar karena Grab pasti memiliki pengendara (biker) yang lulus pelatihan, motor dengan dokumen-dokumen yang lengkap serta perawatan motor yang dilakukan secara rutin. Hal ini mengasumsikan bahwa pengendara motor selain Grab memiliki kemungkinan bahwa mereka tidak semua lulus pelatihan, tidak semua kendaraan motor mereka memiliki dokumen lengkap dan tidak semua motor mereka melakukan perawatan secara rutin.

Berikut adalah beberapa gambar adeganadegan visualisasi iklan video kampanye Grab. Peneliti mencoba mengintepretasikan adan menjelaskan gambar-gambar yang berada dalam iklan video kampanye tersebut sesuai dengan data interview dari informan-informan yang telah melihat iklan Grab tersebut dan melalui analisis interaksi simbolik.

Pada Gambar 2, gambar tersebut menunjukkan seorang mahasiswa berumur sekitar 20-an bernama Dinda (sesuai dengan over-voice). Dinda sedang berjalan dalam 


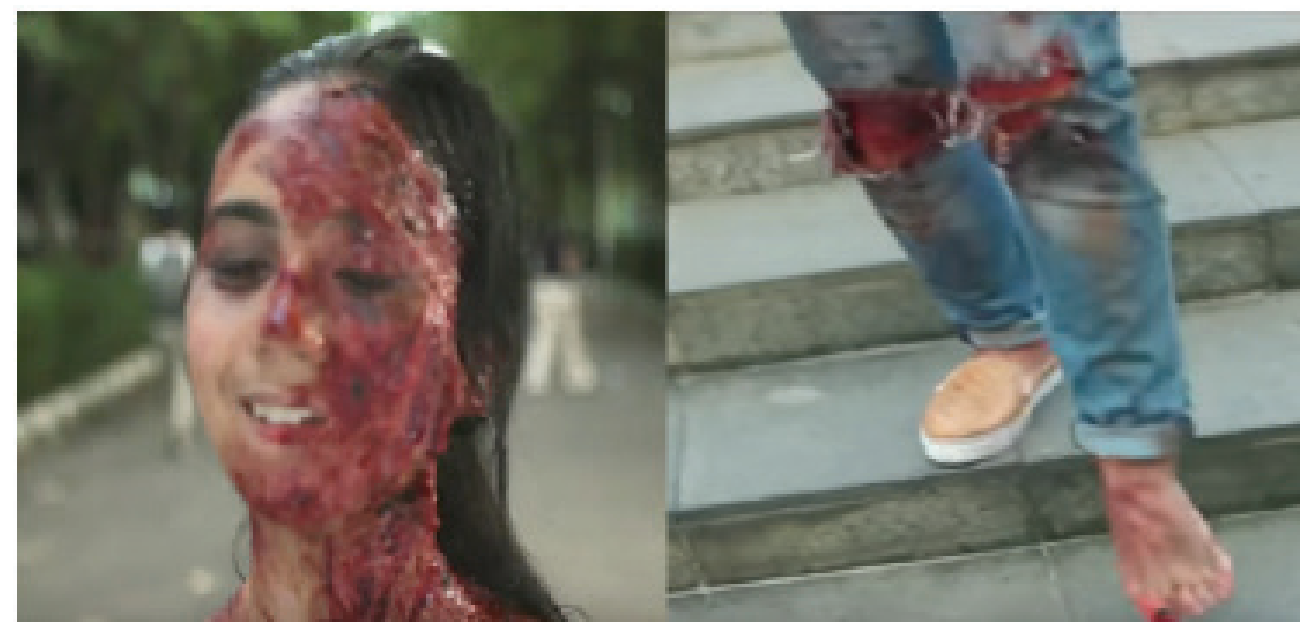

sumber:https://www.youtube.com/watch?v=IIV8Rosy5aw, 2018

Gambar 3 Dinda dengan luka wajah berdarah serta celana panjang Dinda sobek dan sepatu hilang satu yang mengindikasi 'kecelakaan'

kampusnya dan terlihat mengarah keluar kampus. Ini ditunjukkan melalui lingkungan remaja yang hilirmudik membawa perlengkapan kemahasiswaan, dan terlihat memiliki umur yang sama dengan Dinda adapun gedung gedung yang menjadi latar belakang atau set lokasi tempat. Gedung-gedung tersebut disimbolisasikan sebagai kampus, tempat mahasiswa belajar. Dinda dalam adegan ini tampak berseri-seri dan didukung oleh overvoice yang menceritakan mimpi Dinda sebagai seorang penyanyi.Ketika Dinda sedang terus berjalan keluar kampusnya, tiba-tiba terdapat luka-luka yang perlahan-lahan timbul di muka Dinda. Seiring Dinda berjalan menuju keluar, luka yang ada di muka Dinda bertambah. Hal ini diiringi oleh voice-over yang menekankan apabila Dinda tidak mengambil keputusan yang benar, ia tidak akan bertemu dengan temantemannya, ibunya dan bapaknya lagi. Video ini juga diiringi oleh sebuah musik audio yang terkesan menyedihkan

Gambar 3 memperlihatkan celana Dinda yang robek dan kedua lutut Dinda terlihat terluka dan berdarah. Hal ini mengindikasikan Dinda telah mengalami kecelakaan, ditambah dengan satu kaki yang kehilangan sepatu, dan jempol kaki yang berdarah dan terluka. Luka yang dialami Dinda di wajah semakin parah dan terlihat banyak darah. Gambar muka Dinda inilah yang disebut sebagai bagian yang "menyeramkan" oleh beberapa informan. Hal ini juga disayangkan dipertontonkan karena banyak darah ini tidak baik dikonsumsi oleh mereka yang masih di bawah umur. Pada adegan ini audio musik yang mengiringi voiceover masih terkesan menyedihkan, karena berupaka menekankan kalimat "Dinda nggak bakal ketemu teman-temannya lagi..ibunya atau saya lagi”. 


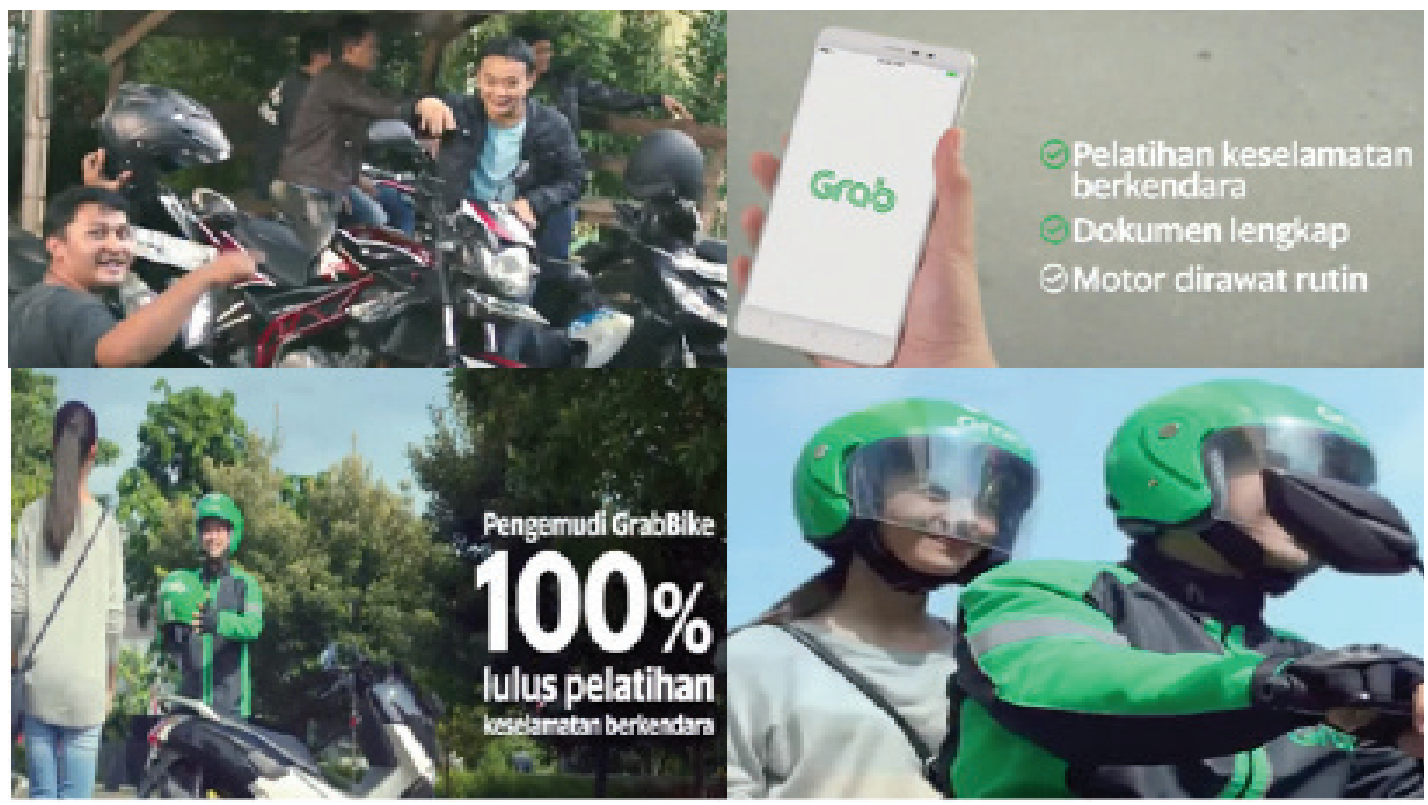

sumber:https://www.youtube.com/watch?v=IIV8Rosy5aw, 2018

Gambar 4 Adegan akhir dari iklan Grab \#PilihAman

Gambar 4 memperlihatkan beberapa adegan dalam iklan Grab \#PilihAman yang merupakan adegan-adegan terakhir pada detikdetik terakhir. Pertama, ketika Dinda keluar kampus ia melihat dua ojek pangkalan yang menawarkan jasa mereka pada Dinda. Ojek pangkalan tersebut terlihat dari adanya beberapa motor yang terparkir dan adanya beberapa pria yang sedang duduk di tempat mereka menunggu penumpang. Kebiasaan para ojek pangkalan adalah saling berinteraksi selama mereka menunggu penumpang. Biasanya ojek pangkalan mengantri satu dengan lainnya untuk mendapatkan penumpang. Dalam adegan ini, Dinda terlihat melihat kepada ojek-ojek pangkalan tersebut namun memilih untuk membuka smartphone-nya dan membuka aplikasi Grab.

Gambar selanjutnya menunjukkan tampilan aplikasi Grab, adegan ini memperlihatkan bahwa Dinda memilih untuk memesan Grab bike dibandingkan ojek-ojek pangkalan. Hal ini juga ditekankan oleh voice-over yang menekankan bahwa dengan memilih Grab ada tiga hal yang menguntungkan yaitu bahwa para pengendara Grab melakukan pelatihan keselamatan berkendara, memiliki dokumen yang lengkap serta melakukan perawatan motor yang rutin. Pada adegan ini, adanya perubahan audio musik, yang awalnya audio terkesan sedih, kemudian berubah menjadi musik yang lebih ceria dan mengembirakan. Hal ini lebih ditakankan ketika Voice-over mengatakan“.. Tapi Dinda memilih yang benar..". kemudian voice-over berganti yang awalnya bapaknya Dinda, digantikan suara lain yang seolah-olah merupakan suara dari pihak Grab.

Adegan kemudian dilanjutkan dengan 
memperlihatkan dengan jelas bagaimana Dinda memilih jasa Grab dibandingkan para ojek pangkalan. Karena ojek-ojek pangkalan terlihat sangat jelas berada di bagian kanan Dinda. Adegan tersebut juga memperlihatkan bagaimana kelengkapan seorang supir Grab bike ketika berkendara. Ia menggunakan jaket rapih dan sopan, (jaket seragam Grab bernuansa hijau) dan helmet yang dipakai terkesan aman dapat melindungi kepala. Adegan ini ingin menekankan penonton bahwa dengan memilih jasa Grab, keselamatan seseorang akan terjamin. Muka Dinda yang awalnya penuh luka dan berdarah mendadak menghilang dan tidak terlihat lagi. Hal ini kemudian jugaditekankan oleh over voice yang mengatakan 'karena anda tak tergantikan', dan audio musik yang ceria.

Gambaran iklan diatas menunjukkan bagaimana iklan Grab \#PilihAman ini mencoba menarik perhatian penonton. Seperti yang dikatakan oleh Potter, pengiklan menggunakan puffery atau pujian secara berlebihan untuk menekankan kebenaran. Iklan video kampanye Grab \#Pilih Aman menggunakan empat taktik yang disebutkan Potter yaitu Pseudo-claims, comparison with an unidentified other, irrelevant comparisons dan juxtaposition (Potter, 2014).

Pseudo-claims, pada iklan video kampanye Grab \#PilihAman ada over-voice yang mengklaim tiga hal: (a) Pelatihan Keselamatan dengan tulisan verbal tambahan di bagian akhir:
"Pengemudi Grab Bike 100\% lulus pelatihan keselamatan berkendara"; (b) Dokumen lengkap; dan (c) Motor dirawat rutin. Ketiga klaim tersebut dapat dikatakan Pseudo-claims karena tidak ada bukti lanjutannya. Tidak ada informasi bagaimana lulusnya dan bagaimana derajat kelulusannya. Penyampaian klaimklaim tersebut seolah-olah menekankan bahwa hanya Grab Bike yang lulus pelatihan, memiliki dokumen yang lengkap dan selalu merawat motornya secara rutin. Adanya visualisasi Ojek pangkalan dalam iklan tersebut memberikan kesan bahwa para ojek pangkalan tersebut ada yang tidak lulus dalam pelatihan keselamatan atau bahkan sama sekali tidak ikut pelatihan keselamatan.

Comparison with an unidentified other, pada iklan video kampanye Grab \#PilihAman, Grab membandingkan dengan pihak lainnya meskipun tidak secara terbuka dikatakan 'para ojek pangkalan' namun, secara kasat mata gambar pada adegan iklan tersebut memperlihatkan bahwa bandingan yang tidak diidentifikasikan merupakan para ojek pangkalan. Ini terlihat dari ciri-ciri pria-pria yang menawarkan Dinda untuk memilih jasa angkut mereka. Pebandingan ini memang tidak vulgar secara verbal, namun vulgar secara nonverbal.

Irrelevant comparisons, pada iklan video kampanye Grab \#PilihAman, ada voice-over 
yang mengatakan bahwa Dinda memilih yang benar. Sedangkan tidak dijelaskan mana pilihan yang salah. Sehingga objek perbandingannya tidak relevan dan tidak bisa dibuktikan kebenarannya.

Juxtaposition, pada iklan video kampanye Grab \#PilihAman, terlihat bahwa aktor perempuan yang bernama Dinda pada adegan terakhir memilih Grab dan ketika aktor tersebut berkendara diatasnya sebagai penumpang, ia terlihat tersenyum yang mengasumsikan bahwa ia senang dan puas telah memilih sebuah pilihan yang bener. Hal ini terlihat pada gambar 9 dibawah. Senyuman memberikan simbol yang memiliki makna bahagia dan senang. Senyuman Dinda yang terlihat pada gambar 9 ini dilakukan ketika Dinda sedang naik jasa layanan Grab. Hal ini disebut sebagai taktik Juxtaposition, yang mengindikasikan bahwa adanya kesan bahagia, senang dan puas ketika menggunakan produk pengiklan tersebut.

Menurut pemerhati industri iklan Indonesia, Ridwan Sanjoyo, Selasa (20/9/2016) mengatakan pelanggaran etika perikanan dilakukan oleh Grab karena ditampilkan di media sosial sehingga bisa diakses dengan bebas oleh pemirsa dari berbagai usia. Selanjutnya penayangan iklan ini juga dirasa kurang tepat karena berbau kekerasan atau sesuatu hal yang sangat mengerikan.Meski pesan yang disampaikan adalah keselamatan berkendara, lanjutnya, iklan tersebut tidak tepat dan terlalu vulgar (Aditya, 2016).

Selain kontennya yang sensitif seperti gambar diatas, Ridwan juga mengatakan bahwa iklan Grab ini juga dianggap overclaim. Sebab, klaim yang menyebut bahwa menggunakan Grab lebih aman dari ojek konvensional belum bisa dipertanggungjawabkan. Hal itu karena tidak ada jaminan 100\% bahwa menggunakan jasa Grab tidak akan mengalami kecelakaan. Seluruh moda transportasi tentunya memiliki risiko kecelakaan. Ridwan menilai, dasar klaim yang disajikan dalam iklan tersebut haruslah dipertanyakan. Terutama, bagian membandingkan dengan ojek pangkalan dengan cara kurang etis (Aditya, 2016).

Wati adalah seorang pembantu rumah tangga yang biasa menggunakan baik jasa Grab bike maupun jasa pangkalan ojek. Wati tidak begitu memahami maksud dan tujuan dari iklan tersebut. Ia mengintepretasikan luka-luka yang tampak secara tiba-tiba pada perempuan tersebut sebagai hal-hal yang negatif yang mungkin terjadi, seperti kecelakaan, perampokan ataupun pemerkosaan. Namun ia menyatakan bahwa iklan tersebut terlalu berlebihan. Kecelakaan menurut pandangannya bukan terjadi karena pemilihan kita antara supir ojek pangkalan maupun Grab bike, namun tergantung pada supirnya. Meskipun Wati mengakui bahwa ia setuju memilih Grab bike dibandingkan ojek 
pangkalan ketika mempertimbangkan masalah keselamatan, namun iklan tersebut dianggap terlalu berlebihan (Wati, 2019).

Dian seorang pemerhati iklan yang melihat dari segi teknisnya menyatakan bahwa iklan Grab tersebut terlalu berlebihan, frontal dan ofensif dan menyayangkannya. Ia berpendapat bahwa masyarakat yang tidak terliterasi akan dengan mudah beranggapan bahwa dengan naik kendaraan lain selain 'Grab Bike" akan mengalami kecelakaan yang fatal. Dian mengungkapkan:

“...ini adalah penyerangan seperti 'black campaign' terhadap pesaing-pesaingnya apalagi dengan adanya ungkapan '..Dinda memilih yang benar'..ini berarti yang lain adalah salah, dan jika salah maka akan mengalami kecelakaan seperti itu," (Dian, 2019).

Septian Dwi Wibowo (22 tahun), mahasiswa Universitas Padjadjaran, Fakultas Hukum, menyatakan bahwa penggambaran iklan tersebut terlalu berlebihan. "Karena tidak sebegitunya juga jika kita naik ojek pangkalan. Tidak semua driver ojek pangkalan memiliki image seperti itu, apalagi penggambaran dampak dari pemilihan ojek pangkalan sebagai sarana transportasi juga tidak segitunya," (Wibowo, 2019). Wibowo juga mengakui bahwa pihak Grab tidak sesempurna itu. Menurut pengalamannya, ia pernah menemui driver yang kurang berbakat, motor yang tidak terawat, walaupun untuk perihal dokumen memang sudah pasti diharuskan lengkap.

Wibowo menjelaskan bagaimana Iklan Grab tersebut tidak melanggar norma, namun lebih mengarah ke melanggar etika yang ada di dalam masyarakat. "Dilihat dari segi hukum, memang hal ofensif atau menyerang dalam bentuk apapun itu bisa dikasuskan. Tetapi khusus untuk iklan Grab kali ini masih belum begitu kuat bagi saya. Karena subyek yang diserang masih bersifat umum dan luas, serta tidak terlembagakan," (Wibowo, 2019).

Neyla merupakan salah satu informan termuda yang biasa mengakses internet dan sering terpapar oleh berbagai iklan, termaksud iklan Grab versi "Dina anak saya' dengan hasgtag \#Pilihaman. Neyla merasa iklan Grab tersebut tidak baik dan secara visualisasi, simbol-simbol yang diperllihatkan menakutkan. Neyla juga mengakui bahwa iklan tersebut menjatuhkan pihak lain khususnya para ojek pangkalan. Hal ini dianggap tidak adil dan tidak baik. Iklan tersebut terlalu berlebihan dan kurang etis (Neyla, 2019).

Vanya yang juga merupakan salah satu informan termuda dan telah melihat iklan video kampanye Grab \#PilihAman mengatakan bahwa iklan tersebut menakutkan karena persepsi Vanya setelah menonton iklan tersebut, ia mengasumsikan bahwa seseorang akan mengalami kecelakaan apabila tidak memilih 
Grab. Hal ini disebut vanya kurang relevan dan tidak baik karena terlalu berlebihan (Vanya, 2019).

Menurut Aulia, yang merupakan seorang pegawai negeri, ia melihat iklan Grab \#PilihAman terlalu ekstrim untuk standar sebuah iklan. Aulia mengakui bahwa iklan tersebut tidak biasa dan cukup mindblowing, tetapi pengemasan dan penggambarannya kurang baik untuk dilihat. Hal yang kurang disetujui adalah visualisasi iklan tersebut yang secara langsung memperlihatkan bahwa Grab lebih baik daripada ojek pangkalan (Aulia, 2019).

Dilihat dari analisis interaksi simbolik iklan video kampanye Grab \#PilihAman dapat mencuri perhatian target audiens melalui elemen-elemen visualnya. Meskipun informaninforman yang menjadi subjek penelitian memaparkan bagaimana iklan tersebut dianggap kurang layak untuk ditayangkan karena selain terlalu berlebihan, terlalu ekstrim, bersifat ofensif serta tidak etis. Tokoh perempuan yang dipanggil sebagai Dinda mengalami luka di wajahnya yang lama kelamaan bertambah dan memberikan kesan menyeramkan dan vulgar. Mulai dari darah yang ada di mana-mana, celana sobek, dan sepatu yang hilang sebelah. Secara simbolik, makna darah dan luka dalam iklan tersebut mencerminkan suatu kecelakaan yang terjadi. Meskiun kecelakaan itu sendiri tidak diperlihatkan. Terdapat pesan tanpa sadar dari adegan tersebut, ketika over-voice mengatakan jika Dinda tidak memilih dengan bener maka akan terjadi sebuah hal buruk pada Dinda. Memilih Grab adalah putusan yang benar dibandingkan memilih ojek pangkalan.

Menurut interaksi simbolik manusia berinteraksi menggunakan simbol-simbol yang memiliki makna dan terinternalisasi melalui budaya dan kebiasaan, peneliti melihat bahwa adanya upaya aktif para informan dalam mengintepretasikan simbol-simbol yang ada dalam iklan Grab \#PilihAman. Mereka juga memaknai simbol-simbol tersebut sesuai dengan budaya dan kebiasaan yang ada di Indonesia. Seperti pengambaran beberapa laki-laki yang memanggil Dinda di sebuah lokasi dekat kampus, dimana mereka terlihat memiliki sepeda motor dan beberapa dari mereka menggunakan jaket yang terlihat pada gambar empat. Semua informan sama-sama memaknainya sebagai ojek pangkalan yang biasa menunggu penumpang pada lokasi-lokasi tertentu yang strategis.

Pengambaran Dinda yang penuh luka pada wajah dan tubuhnya oleh semua informan diasumsikan sebagai kecelakaan yang mungkin akan dialami Dinda jika tidak memilih Grab relevan dengan salah satu elemen dasar Interaksi simbolik mengenai'shared subjective agreement' dan'shared symbols' 
,yang menandakan bahwa adanya persetujuan subjektif dan pemahaman simbol secara bersama.

Sebuah iklan dikatakan tidak etis jika memiliki upaya menjatohkan pesaing lainnya. "An advertisement is considered to be unethical if it attempts to damage the competitors 'product or service and conveying wrong or misleading information, making overstated claims, and effects people lives in a negative manner" (Huq, Nekmahmud, \& Aktar, 2016). Sehingga visualisasi yang memperlihatkan pria-pria yang menawarkan Dinda yang merupakan simbol ojek pangkalan ini dianggap tidak etis, karena secara vulgar menjatohkan pesaing dari Grab itu sendiri.

Elemen audio yaitu musik atau jingle pada awal iklan video kampanye Grab \#PilihAman di awali dengan musik yang lamban atau slow dan terkesan sedih. Namun, ketika iklan berdurasi 45 tersebut sudah mulai memperlihatkan bagaimana Dinda memilih Grab sebagai pilihan yang benar, audio berubah menjadi musik yang lebih penuh keceriaan. Hal ini memperkuat kampanye \#PilihAman secara keseluruhan. Dari beberapa sudut pandang dan asumsi, semua informan setuju bahwa iklan Grab \#PilihAman memang tidak layak ditayangkan dan penarikan iklan tersebut merupakan keputusan yang benar, namun hal ini tidak memperngaruhi masyarakat untuk tidak memilih Grab sebagai alternatif transportasi mereka. Mereka tetap menggunakannya, bahkan ada kecenderungan meningkat.

\section{SIMPULAN}

Pemaparan diatas mengemukakan beberapa hal dalam menggambarkan dua tujuan penelitian ini. Pertama adalah mengenai bagaimana iklan video Grab \#PilihAman menggunakan pujian dalam menekankan kebenaran. Ada empat cara iklan tersebut melakukannya: (1) Pseudo-claims, pada iklan video kampanye Grab \#PilihAman menggunkan klaim-klaim yang tidak disertakan bukti kebenarannya; (2) Comparison with an unidentified other, pada iklan video kampanye Grab \#PilihAman, iklan tersebut membandingkan dengan pihak lain yang tidak diidentifikasikan secara jelas; (3) Irrelevant comparisons, pada iklan video kampanye Grab \#PilihAman, ada voice-over yang mengatakan bahwa 'Dinda memilih yang benar'. Sedangkan tidak dijelaskan mana pilihan yang salah; dan (4) Juxtaposition, iklan menggunakan aktor Dinda untuk tersenyum ketika berkendara menggunakan GrabBike yang menandakan bahwa Dinda puas telah memilih jasa tersebut.

Hal kedua menjawab tujuan penelitian untuk mendeskripsikan bagaimana penonton melihatiklan video kampanye Grab\#PilihAman, yaitu: (1) Ofensif, iklan video kampanye Grab 
\#PilihAman dilihat sebagai iklan yang ofensif karena secara eksplisit menyerang saingan Grab yaitu ojek pangkalan. 'black campaign' juga disebutkan sebagai akibat dari iklan Grab ini yang tampak menjatohkan ojek pangkalan; (2) Berlebihan (Overclaim), iklan video kampanye Grab \#PilihAman dianggap berlebihan karena menyatakan klaim-klaim yang tidak terbuktikan kebenarannya. Baik secara verbal maupun nonverbal; (3) Ekstrim, iklan video kampanye Grab \#PilihAman dianggap terlalu ekstrim karena meneksplisitkan kejadian terburuk dalam berkenadaraan apabila memilih yang tidak benar. Visualisasi video tersebut dianggap ekstrim karena mempertontonkan banyak darah dan luka; dan (4) Tidak etis, Iklan video kampanye Grab \#PilihAman dianggap tidak etis karena dilihat menjatuhkan lawan kompetisi dalam layanan transportasi, dalam hal ini ojek pangkalan.

Uraian diatas menyimpulkan bahwa adanya taktik dan strategi yang dilakukan pihak Grab dalam menarik audiensi, cara-cara yang ditempuh pada versi iklan Grab \#PilihAman ini ternyata menimbulkan reaksi dari para audiens. Semua informan merasa bahwa iklan tersebut ofensif dan juga sensitif sehingga tidak layak untuk ditayangkan. Meskipun iklan tersebut pada akhirnya ditarik peredarannya oleh pihak Grab, namun masih dapat di akses melalui Youtube. Konten iklan Grab \#PilihAman tidak memberikan pengaruh signifikan terhadap perkembangan bisnis Grab itu sendiri. Hal ini dikarenakan adanya iklan-iklan lainnya dari Grab yang mengundang penonton untuk tetap memilih Grab.

Peneliti menyarankan beberapa hal terkait pembuatan konten iklan yaitu agar pengiklan mempertimbangkan beberapa simbol yang terkait budaya dan kebiasaan masyarakat serta mengkaji ulang bagaimana agar sebuah iklan tidak bernuansi menyerang pihak pesaing dalam sebuah produk barang maupun jasa. Saran berikutnya ditujukan kepada masyarakat agar mengikuti berbagai lokakarya yang berkaitan dengan literasi media.

\section{DAFTAR PUSTAKA}

Aditya, A. (2016, September 20). Kontroversi Iklan Grab: Pengamat Nilai \#Pilihaman Tak Etis. Retrieved from Kabar24. Bisnis.Com: https://kabar24.bisnis.com/ $\mathrm{read} / 20160920 / 15 / 585569 /$ kontroversiiklan-grab-pengamat-nilai-pilihaman-taketis

Ammarie, R. H., \& Nurfebiaraning, S. (2018). Pengaruh iklan pop-up bukalapak versi pahlawan pada youtube terhadap sikap khalayak. Jurnal Manajemen Komunikasi, 2(2), 78-94. doi:10.24198/jmk.v2i2.12871

Aulia. (2019). Wawancara. (S. S. Indriani, Interviewer)

Azzahrani, M. (2018). Strategi komunikasi pemasaran kementerian pariwisata Indonesia dalam pesona indonesia melalui youtube. Jurnal Manajemen Komunikasi, 
2(2), 144-161. doi:10.24198/jmk. v2i2.12925

Baskoro, F. M. (2018, September 8). beritasatu. com. Retrieved from Berita Satu: https:// www.beritasatu.com/ekonomi/509401/ belanja-iklan-tv-asian-games-mencapairp-747-m

Bohang, F. K. (2016, September 20). Kompas.com. Retrieved from kompas. com: https://tekno.kompas.com/ $\mathrm{read} / 2016 / 09 / 20 / 07562837 / \mathrm{iklan}$. pilihaman.grab.dikecam.netizen.

Dapu, S. M., Kawengian, D. D., \& Waleleng, G. (2015). Persepsi khalayak terhadap iklan aqua botol tanpa segel plastik (Studi di Kelurahan Malalayang I Timur Kota Manado). Acta Diurna, 4(3), 1-10.

DH, P. (2016, Maret 30). bitebrands.co. Retrieved from Bite Brands.co: https:// www.bitebrands.co/2016/12/iklan-palingkontroversial-di-indonesia-kritikankecaman-dilarang.html

Dian. (2019). Wawancara. (S. S. Indriani, Interviewer)

Fauziah, D., \& Puspita, R. (2018). Analisis semiotika john fiske mengenai realitas bias gender pada iklan kisah ramadhan line versi adzan ayah. ProTVF: Jurnal Kajian Televisi Dan Film, 2(2), 157-171.

Gehi, A. (2013, September 14). slideshare.net. Retrieved from Slide Share.net: https:// www.slideshare.net/amitgehi/unethicaladvertisements-26191813

Grab.com. (2016, September 16). Retrieved from www.grab.com: https:/www.grab. $\mathrm{com} / \mathrm{id} / \mathrm{blog} /$ lebih-baik-pilihaman-dijalan-daripada-menyesal-kemudian/

Hakim, R. T., \& Susilowati, C. (2013). Pengaruh persepsi iklan, kesadaran merek, citra merek terhadap sikap pada merek dan keputusan pembelian (studi pada produk pestisida merek sidamethrin 50 EC). Jurnal Aplikasi Manajemen, 11(4), 537-546.

Harry. (2018, November 6). Pasar Dana. id. Retrieved from PasarDana: https:// pasardana.id/news/2018/11/6/belanjaiklan-januari-september-2018-tumbuh-5persen-dengan-total-mencapai-rp-114-4triliun/

Huq, S. M., Nekmahmud, M., \& Aktar, M. S. (2016). Unethical practices of advertising in bangladesh: a case study on some selective products. International Journal of Economics, Finance and Management Sciences, 4(1), 10-19.

Kotler, P., \& Keller, K. L. (2009). Manajemen pemasaran. Jakarta: Erlangga.

Lubis, M. (2018). www.nielson.com. Retrieved from Press Room: https://www.nielsen. com/id/en/press-room/2018/PertumbuhanBelanja-Iklan-2017-Bergerak-PositifNamun-Melambat.html

Mulyadi, U., \& Fitriana, L. (2018). Hashtag (\#) as Message Identity in Virtual Community. Jurnal The Messenger: Cultural Studies, IMC and Media, 10(1),44-53.doi:10.26623/ themessenger.v10i1.671

Mulyana, D. (2001). Metode Penelitian Kualitatif. Bandung: Remaja Rosdakarya.

Neyla. (2019). Wawancara. (S. S. Indriani, Interviewer)

Nurfebiaraning, S. (2016). Strategi kreatif pesan video advertising "oreo penuh keajaiban" pada youtube. channel: Jurnal Komunikasi, 4(1), 35-46. doi:10.12928/ channel.v4i1.4205

Permana, R. S., Puspitasari, L., \& Indriani, S. (2018). Strategi promosi pada tahapan praproduksi film 'haji asrama'(HAS). ProTVF: Jurnal Kajian Televisi Dan Film, 2(2), 145156. doi:10.24198/ptvf.v2i2.20818

Potter, W. J. (2014). Media literacy. Los 
Angeles: SAGE.

Rakhmat, J. (2013). Psikologi komunikasi. Bandung: Remaja Rosdakarya.

Ritzer, G. (2014). Teori sosiologi modern. Jakarta: Prenadamedia Group.

Triesie, D., Weigold, F. M., Conna, J., \& Garrison, H. (1994). Ethics in advertising: ideological correlates of consumer perceptions. Journal of Advertising, 23(3), 59-69.

Utami, R. P. (2018, 8 19). sripoku.com. Retrieved from Sripoku.com: http:// palembang.tribunnews.com/

Vanya. (2019). Wawancara. (S. S. Indriani, Interviewer)

Walgito, B. (2004). Pengantar psikologi umum. Yogyakarta: Andi.

Wati. (2019). Wawancara. (S. S. Indriani, Interviewer)

Wibowo, S. D. (2019). Wawancara. (S. S. Indriani, Interviewer)

Winarni, R. W. (2010). Representasi Kecantikan Perempuan Dalam Iklan. DEIKSIS, 2(2), 134-152. doi:10.30998/deiksis.v2i02.399 